\title{
STUDENTS' PERCEPTION REGARDING ONLINE LEARNING IMPLEMENTATION DURING THE PANDEMIC IN STIE BINA KARYA
}

\author{
Haya Haratikka1, Sri Winda Hardiyanti Damanik², Rapat Piter Sony ${ }^{3}$ \\ 1,2,3 Sekolah Tinggi Ilmu Ekonomi Bina Karya \\ ${ }^{1}$ hayaharatikka@gmail.com, ${ }^{2}$ sriwindahardiyantid@gmail.com, ${ }^{3}$ piter.pospos@gmail.com
}

\begin{abstract}
Covid 19 has evolved and impacted the education system in the world, including Indonesia. This situation reshapes the education system, from traditional classroom to virtual classroom. This study was a qualitative which took thirty seven informants. The informants were the students of STIE Bina Karya's students who has experienced two semesters during the pandemic. The data collection technique was the open ended questionaires. Then, analyzed using the thematic analysis. This study was going to discover students' perception during the pandemic. The results showed that students' perception regarding to the implementation of online learning in STIE Bina Karya during the pandemic were negative mostly. However, the online learning povides some advantages too for students, although students cannot pull to one side from the disadvantages they got.
\end{abstract}

Keywords: Online Learning, Perception, Disadvantages, Advantages

\section{INTRODUCTION}

March 2020, the covid -19 has outbraked in Indonesia which give impact to education system. In order to continue the education sytem, the Ministry of Education and Culture prepared all scenarios planning, that is implementing the online learning (e-learning) (Abidah et al., 2020). Previously, online learning were conducted in order to keep balance between the learners' carrer and education achievement (Dhirendra Kumar, 2015).

According to Stern (2018), online learning is the situation when the education maximalized the use of internet. Besides, online learning made the learning process more active, interesting and enjoyable because teachers can enhance learners learning skills through innovative ways using the technology. Teaching and learning materials are shared and offered in various format like slides, videos, audios, PDFs, emails, and word documents which are free access. Furthermore, online learning provides clear and easy instruction which are suitable for self learning (Arkorful \& Abaidoo, 2015). Online learning also provides some benefits for students. Students can do their works anytime and anywhere that is more compatible and convenience with their learning needs. Not only that, students are saved from the parking issues, traffic, and other possible barriers which may happen when attending the face to face learning. Definitely, these distractions will affect students' ability to focus on the learning content (Gilbert et al., 2015). In online learning, teacher and students are able to communicate synchronously (directly) and asynchronously (indirectly) through internet using several platforms (Rosali et al., 2020) within the use of electronic devices (Atmojo \& Nugroho, 2020). As Arizona et al. (2020) said that Google Classroom and Edmodo are able to manage the classical online learning effectively. Besides, there are twelve free accessed online platforms as learning media and sources in this pandemic, those are Rumah Belajar, Meja Kita, Icando, Indonesia X, Google for Education, 
Kelas Pintar, Microsoft Office 365, Quipper School, Ruangguru, Sekolahmu, Zenius and Cisco Webex. However, there are some popular platforms as the learning media in universities, those are Google Classroom, Zoom Meeting, Whatsapp, GoogleMeet (Haqien \& Rahman, 2020). In this global lockdown, many countries in Asia provide learning materials as needed by the learners, then upload them on online platform (Soni, 2020). Having the effective and intensive communication, not only the dialog between teacher and student but also the learner autonomy will succeeded the online learning (Sadeghi, 2019).

STIE Bina Karya is one of universities in North Sumatra which implements the e learning in this pandemic. In teaching and learning process, the lecturers utilize some platforms; Google Classroom, Whatsapp, Zoom Meeting, and Google Meet. However, these e learning implementation can not run smoothly. There were some problems faced by students who deal with this e learning such as their location do not support the internet network, they do not have enough money to run the online class, they did not understand the content of the material (Herliandry et al., 2020) uploaded by the lecture and at the end of the semester most of them did not satisfied with their final mark and not less of them did not get their final score eventhough they had done all their responsilities in online class. The major problem comes from students who are from low-income families and live in rural areas (Azzahra, 2020). Kumar states there are several disadvantages of online learning implementation: 1) Limited social interaction, 2) Technology cost and scheduling, 3) problematic for instructors (Dhirendra Kumar, 2015), 4) The bad internet connectioncan frustrate learners because the learning content relies on a lot of videos and audios, 5) students assessment and feedback are limited, and 6) computer is not at all right for learning process (James, 2002). In addition, as Mustakin said that utilizing the handphone for the long duration and the intensive usage in completing the assignments will affect learners' phisically like the eyes disorder, headache, feel sleepy, and also hard to sleep and other complaints (Mustakim, 2020).

After almost two semesters running the online learning, what are STIE Bina Karya students' perceptions regarding e learning implementation during the pandemic with no face to face learning? Perception is the human abilities in optimalizing their five senses from the outside world, then the sensory organs allow us to recognize and identify the existence stimuli and then evaluate and give meaning. Perception process has three stages, those are: 1) selection, 2) organizing, and 3) interpretation (Qiong, 2017). The purpose of this study is to see students' perception regarding e learning implementation during the pandemic in STIE Bina Karya without face to face learning.

\section{METHOD}

This was a qualitative reserach which implemented ramdom sampling. There were thirty seven informants who represent the 3rd, 5th, and 7th semester in this year, 2020. The informants of this study were STIE Bina Karya students from management study program who has taken online learning for almost two semesters. The researchers conducted online survey to gain the data since physical contact is not permitted. An open ended questionaire was distributed as the technique data collection. The data in this study was in form of phrases, sentences, and paragraphs. Thematic analysis were employed as the data analyzing technique. According to (Nowell et al., 2017) there are six steps of analyzing the data: 1) Familiarizing the data, 2) Generating the codes, 3) Searching for the suitable themes, 4) Reviewing themes, 5) Defining and naming themes, 6) Producing the report. 


\section{RESULTS AND DISCUSSION}

\section{Results}

This study discovered STIE Bina Karya students' perception reagrding to online learning implementation during the pandemic situation. The findings of this study were described in the following tables.

Tabel 1. The Advantages and Disadvanatges of Online Learning Implementation

\begin{tabular}{|c|c|}
\hline Advantages & Disadvantages \\
\hline $\begin{array}{l}\text { time and place for conducting learning were } \\
\text { flexible, }\end{array}$ & extra internet data package \\
\hline they can open book when they have test & eye damage \\
\hline $\begin{array}{l}\text { the online learning process was more relaxed } \\
\text { rather than the face to face learning }\end{array}$ & $\begin{array}{l}\text { less understanding on the material, } \\
\text { especially on calculation material }\end{array}$ \\
\hline $\begin{array}{l}\text { no need to dress up properly along the online } \\
\text { class }\end{array}$ & uninteractive communication \\
\hline they can study together with their family at home & the short deadline task submission \\
\hline students have time for taking rest & a lot of task to do at the same time \\
\hline no travel cost & need extra papersheet \\
\hline the learning process was more personal & $\begin{array}{l}\text { the poor internet network made them } \\
\text { difficult to submit their task ontime }\end{array}$ \\
\hline $\begin{array}{l}\text { they have time to help their parents at home for } \\
\text { earning money }\end{array}$ & $\begin{array}{l}\text { test and task submission method was } \\
\text { complicated }\end{array}$ \\
\hline $\begin{array}{l}\text { they are saved from Covid }-19 \text { since they do not } \\
\text { need to go out }\end{array}$ & can not meet each other/classmates \\
\hline $\begin{array}{l}\text { they did not waste their time on the road } \\
\text { the learning material documentation was easier }\end{array}$ & reduced interaction with the lecturer \\
\hline $\begin{array}{l}\text { the class started on time, unlike face to face } \\
\text { learning }\end{array}$ & \\
\hline
\end{tabular}

Personally, online learning implementation provides some advantages and disadvantages for students as seen on table 1. After gaining the data, the researchers found there were thirteen advantages of online learning implementation and eleven disadvantages. The advantages were 1) time and place for conducting learning were flexible, 2) they can open book when they have test, 3) the online learning process was more relaxed rather than the face to face learning, 4) no need to dressed up properly along the online class, 5) students have time for taking rest, 6) no fare, 7) the learning process was more personal, 8) they have time to help their parents at home for earning money, 9) they are saved from Covid -19 since they do not need to go out, 10) they did not waste their time on the road, 11) the learning material documentation was easier, 12) the class started on time, unlike face to face learning, and 13) they can study together with their family at home. The data gainned from the informants were alike with Shivangi (2020), he stated that online learning serves the flexibility because a learner can schedule or plan their time for the online course completion at anytime and anywhere learner can learn independently. This condition would save and protect society from the outbrake transmittion (Dhawan, 2020). According to James, conducting the online learning will minimize the travel cost and time saving (James, 2002). Learners no need to sacrifice their money and time in order to have the face to face class.

Meanwhile the disadvantages were 1) extra internet data package, 2) eye damage, 3) less understanding on the material, 4) uninteractive communication, 5) the short deadline task submission, 6) a lot of task to do at the same time, 7) need extra papersheet, 8) the poor internet 
network made them difficult to submit their task ontime, 9) test and task submission method was complicated, 10) can not meet each other/classmates, and 11) reduced interaction with the lecturer. As Surkhali et al states that the online learning implementation gives the disadvantages too. There are several disadvantages of online learning implementation during the pandemic:1) Students have opportunity to do the plagiarsm work, 2) the poor internet signal will make learners become frustrating, 3) it is possible if not all students have the supporting devices, 4) insufficient technical skill in running the virtual class for both learning participants, 5) feeling of isolation and no interaction, 6) two ways communication, 7) unbeneficial group discussion in virtual class since learning participants cannot deliver their emotions that will bring into less encouragement and less enthusiasm, 8) spending a lot of hours in front of the computer/handphone could produce negative physical effect such as visual discomfort, exhaustion, and muscle and joint ache. Definitely, if this happened continuously it will affect students academic achievement and also mental distress (Surkhali \& Garbuja, 2020). Almost in all education institution faced the same problems regarding to online learning implementation during the pandemic.

Tabel 2. Students' Learning Material Understanding

\begin{tabular}{lll}
\hline Face to Face Learning & Understand & $\mathbf{2 8}$ students \\
\cline { 2 - 3 } & Not understand & 9 students \\
\hline \multirow{2}{*}{ Online Learning } & Understand & 4 students \\
\cline { 2 - 3 } & Not understand & 33 students \\
\hline
\end{tabular}

Table 2 displays the comparison students' learning material understanding between face to face learning and online learning. It shows that informants' understanding during the online learning were so poor. As Cahyani et al said that in online learning, it is difficult for teacher to control students' learning atmosphere since it is restricted on virtual class. As the result, students' learning motivation are getting low. Even their learning achievement get down (Cahyani et al., 2020). For them, it was better in face to face learning. In online learning, teachers uploaded the material in the online platform by implementig the technology. However, not all students are familiar with its work. As the result, students did not catch the content of the video or audio (Herliandry et al., 2020)

\begin{tabular}{lll} 
& \multicolumn{1}{c}{ Tabel 3. Students' Social Competency } \\
\hline \multirow{2}{*}{ Face to Face Learning } & Effective & $\mathbf{2 8}$ students \\
\cline { 2 - 3 } & Ineffective & 9 students \\
\hline Online Learning & Effective & 6 students \\
\cline { 2 - 3 } & Ineffective & 31 students \\
\hline
\end{tabular}

Social competency is owed by everyone. It is the ability to integrate mind, feeling, and behaviour in order to have the social tasks achievement (Shanmugasundaram \& Mohamad, 2011). In face to face learning, students had social interactions among them. They will deal with various characters, personality, uniqeness and characteristics in the classroom (Muspiroh, 2015). From table 3, thirty one informants agree that the implementation of online learning is ineffective. Online learning effectiveness depends on the technology, teacher and students characteristics. In online class they did not meet each other, no class discussion, no presentation, no direct interaction among them, everything is limited in virtual class. However, the poor internet network and also the inadequate facilities and infrastructure trigger the online learning effectiveness (Fauziyah, 2020). By looking at the students' location and also their economy background, mostly they live in an area which is considered as the rural area which have the inadequate infrastructure and learning facilities. Definitely, the learning process they have is restricted within the virtual class. Compared with face to face learning, they can involve in 
teaching and learning activities, they have the available lecture who will guide them in a small discussion and answer their questions arise from their learning process. Especially, in calculation subjects. The online learning atmosphere is not supporting for calculation subject. It took times around two and a half hour to discuss one meeting material in face to face learning. The long explanation on video is not enough for learners to acquisite the content of the material. As the result, they were overwhelmed in doing the test.

Tabel 4. Class Activities

\begin{tabular}{llc}
\hline Face to Face Learning & Active & $\mathbf{2 8}$ students \\
\cline { 2 - 3 } & Inactive & 9 students \\
\hline Online Learning & Active & 5 students \\
\cline { 2 - 3 } & Inactive & 32 students \\
\hline
\end{tabular}

As shown in table 4, the social distancing limits people activities, including in the classroom. In online learning, the class they have is the virtual class. Virtual class is one of the technology advance which is provided by some tools to support the active teaching and learning process. Virtual class is utilized to propagate the distance learning, as suggested by our government. It becomes the new environment for students and teachers in learning which contains all the materials needed by the students. In this case, learners play an important role to do the independent learning (student-centred)(Subramaniam \& Kandasamy, 2011). The finding in this study was in the contrary with Sari at al did. It found that students were prefer to technological tools than the printed material for learning (Sari et al., 2020). The fact, in this pandemic situation, the informants agree that the online class utilization has the inactive class, rather than in face to face learning. The independent learning does not attract the informants's willingness for learning. They are not interested in online learning. The interaction they have in virtual class is different from the activities they had in face to face learning.

Tabel 5. Students Acceptance on Online Learning Implementation

\begin{tabular}{lc}
\hline Enjoyable & $\mathbf{5}$ students \\
\hline Unenjoyable & 32 students \\
\hline
\end{tabular}

According to table 5, obviously online learning implementation is unenjoyable. The informants are as the students did not enjoy through online system. Since they cannot interact with their classmates, lectures and other knowledge sources, they cannot understand the teaching video uploaded by the lecturers on Google Classroom, they cannot communicate directly to the lecturer, moreover they did not have particular time to focus on the subjects the have at home, as the result, their achievement in online learning implementation was not better than face to face learning result. Nevertheless, students need to sacrifice not only time but also much money to improve their learning outcomes even it did not work (Yulia, 2020).

\section{Discussion}

After analyzing the data, this research had answered the research problem. As the result, the implementation of online learning during the pandemic in STIE Bina Karya did not run smoothly. Mostly students have the negative perceptions regarding to the online learning implementation during the pandemic. Besides, STIE Bina Karya's students could take the advantages which was more than the disadvantages on online learning implementation. It found that time and place flexibility were the major advantages for students conducting the online learning whereas the major barriers come from the poor internet connection and the extra money to support their online learing. Therefore, by viewing at the students' description on face to face 
learning and online learning, the researchers found that the informants were prefer to face to face learning than online learning. Students' material understanding was better in face to face learning rather than in online learning. They could do class discussion, presentation and peer discussion when they have face to face learning. Thus, their interaction among students and lecturer were more intensively. These prove that social competency and learning activities during the face to face learning were higher than on online learning.

\section{CONCLUSION}

To sum up, the implementation of online learning during the pandemic in STIE Bina Karya provided some advantages and also disadvantages for the students. The students cannot get the material through the virtual class but they need to sacrifice extra money. At the end, their achievements decreased compare with their achievements in face to face learning. Since our government has allowed the new norm for doing the social interaction, it would be better if the students make their time for having the group discussion in a limited number of students.

\section{ACKNOWLEDGMENTS}

We thank our beloved family, parents and friends who support us unlimitedly so this study can be completed and published. Not to forget our students as our informants who made this study complete. We hope this study would be essential for the readers and become a useful reference for the next research.

\section{REFERENCES}

Abidah, A., Hidaayatullaah, H. N., Simamora, R. M., Fehabutar, D., \& Mutakinati, L. (2020). The Impact of Covid-19 to Indonesian Education and Its Relation to the Philosophy of "Merdeka Belajar." Studies in Philosophy of Science and Education, 1(1), 38-49. https://doi.org/10.46627/sipose.v1i1.9

Arizona, K., Abidin, Z., \& Rumansyah, R. (2020). Pembelajaran Online Berbasis Proyek Salah Satu Solusi Kegiatan Belajar Mengajar Di Tengah Pandemi Covid-19. Jurnal Ilmiah Profesi Pendidikan, 5(1), 64-70. https://doi.org/10.29303/jipp.v5i1.111

Arkorful, V., \& Abaidoo, N. (2015). The role of e-learning, advantages and disadvantages of its adoption in higher education. International Journal of Instructional Technology and Distance Learning, 12(1), 29-42.

Atmojo, A. E. P., \& Nugroho, A. (2020). EFL Classes Must Go Online! Teaching Activities and Challenges during COVID-19 Pandemic in Indonesia. Register Journal, 13(1), 4976. https://doi.org/10.18326/rgt.v13i1.49-76

Azzahra, N. F. (2020). Addressing Distance Learning Barriers in Indonesia Amid the Covid-19 Pandemic. Policy Brief, 2, 1-8. https://doi.org/10.6092/unibo/amsacta/6247

Cahyani, A., Listiana, I. D., \& Larasati, S. P. D. (2020). Motivasi Belajar Siswa SMA pada Pembelajaran Daring di Masa Pandemi Covid-19. IQ (Ilmu Al-Qur'an): Jurnal Pendidikan Islam, 3(01), 123-140. https://doi.org/10.37542/iq.v3i01.57

Dhawan, S. (2020). Online Learning: A Panacea in the Time of COVID-19 Crisis. https://doi.org/10.1177/0047239520934018

Dhirendra Kumar. (2015). Pros and cons of online education. NC State Industry Expansion Splutions, 2(1), 1-7. https://www.ies.ncsu.edu/resources/white-papers/pros-and-cons-ofonline-education/

Fauziyah, N. (2020). Dampak Covid-19 Terhadap Efektivitas Pembelajaran Daring Pendidikan Islam. Al-Mau-Izhah, 2(2), 1-11. 
Gilbert, B., John, S., \& College, F. (2015). Online Learning Revealing the Benefits and Challenges How has open access to Fisher Digital Publications benefited you?

Haqien, D., \& Rahman, A. A. (2020). Pemanfaatan Zoom Meeting Untuk Proses Pembelajaran Pada Masa Pandemi Covid-19. SAP (Susunan Artikel Pendidikan), 5(1), 51-56.

Herliandry, L. D., Nurhasanah, Suban, M. E., \& Heru, K. (2020). Transformasi Media Pembelajaran Pada Masa Pandemi Covid-19. Jurnal Teknologi Pendidikan, 22(1), 65-70.

James, G. (2002). Advantages and disadvantages of online learning. Retrieved July, 8, 9-11. http://www.leerbeleving.nl/wbts/nieuw_basics/addis.pdf

Muspiroh, N. (2015). Peran kompetensi sosial guru dalam menciptakan efektifitas pembelajaran. Jurnal Pendidikan Sosial \& Ekonomi, 4(2), 1-19. http://www.syekhnurjati.ac.id/jurnal/index.php/edueksos/article/view/655

Mustakim. (2020). Efektivitas Pembelajaran Daring Menggunakan Media Online Selama Pandemi Covid-19 Pada Mata Pelajaran Matematika the Effectiveness of E-Learning Using Online Media During the Covid-19 Pandemic in Mathematics. Al Asma: Journal of Islamic Education, 2(1), 1-12.

Nowell, L. S., Norris, J. M., White, D. E., \& Moules, N. J. (2017). Thematic Analysis: Striving to Meet the Trustworthiness Criteria. International Journal of Qualitative Methods, 16(1), 1-13. https://doi.org/10.1177/1609406917733847

Qiong, O. U. (2017). A Brief Introduction to Perception. Studies in Literature and Language, 15(4), 18-28. https://doi.org/10.3968/10055

Rosali, E. S., Pendidikan, J., \& Universitas, G. (2020). Aktifitas Pembelajaran Daring Pada Masa Pandemi Covid-19 Di Jurusan Pendidikan Geografi Universitas Siliwangi Tasikmalaya. Geography Science Education Journal (GEOSEE, 1(1), 21-30.

Sadeghi, M. (2019). Manijeh Sadeghi 1. Internasional Journal of Reserach in Englissh (IJREE), March, 80-88.

Sari, A. B. P., Brameswari, C., \& Haratikka, H. (2020). Millennial Lecturers' Attitudes in Incorporating the Online Application in the Efl Classroom. PROJECT (Professional Journal of English Education), 3(3), 337. https://doi.org/10.22460/project.v3i3.p337-347

Shanmugasundaram, U., \& Mohamad, A. R. (2011). Social and emotional competency of beginning teachers. Procedia - Social and Behavioral Sciences, 29, 1788-1796. https://doi.org/10.1016/j.sbspro.2011.11.426

Soni, V. D. (2020). Global Impact of E-learning during COVID 19. SSRN Electronic Journal. https://doi.org/10.2139/ssrn.3630073

Stern, J. (2018). Introduction to Online Teaching and Learning. International Journal of Science Education, 3, 1-10. https://doi.org/10.1002/9781118784235.eeltv06b

Subramaniam, N. K., \& Kandasamy, M. (2011). The virtual classroom: A catalyst for institutional transformation. Australasian Journal of Educational Technology, 27(8), 1388-1412. https://doi.org/10.14742/ajet.900

Surkhali, B., \& Garbuja, K. (2020). Virtual Learning during COVID-19 Pandemic : Pros and Cons. Journal of Lumbini Medical College, 8(1), 19-20.

Yulia, H. (2020). Online Learning to Prevent the Spread of Pandemic Corona Virus in Indonesia. ETERNAL (English Teaching Journal), 11(1), 48-56. https://doi.org/10.26877/eternal.v11i1.6068 